\title{
The Risk of Oil Fund Policy Globally. What about Ethics?
}

\author{
Noralv Veggeland \\ Professor of Public Policy, \\ Inland Norway University of Applied Sciences, Lillehammer, Norway
}

doi: 10.19044/esj.2017.v13n25p43 URL:http://dx.doi.org/10.19044/esj.2017.v13n25p43

\begin{abstract}
The systematic global market risk of the type found in the gigantic Norwegian Oil Fund, called "Government Pension Fund - Global (GPF G)", is discussed at length in this study. The objective is to find out if the risk capital animate ethical venture initiative. In the financial and entrepreneurial literature it has over time become common to relate systematic vulnerability and risk to a long range of factors that might cause imbalance and failure.

Ulrich Beck (1992) postulates that risks today related to innovations and unethical and uncontrolled venture capital have a different significance for everyday life from the risks that applied to previous historical eras. $\mathrm{He}$ claims that human activity, innovation and technology in advanced political and economic modernity produce as a side-effect risks venturing investment. That demands specialised expertise to access and recognize, and are collective, global, and irreversible in their impact.

To abstain from venturing actions are a way out of the dilemma for the investors. The Norwegian petroleum activity under regulatory management and control is an example of that. The Fund's revenues have been shrinking lately following the oil prices of the market diving down globally.

Perhaps the Norwegian Oil Fund is to be restructured in a framework of ethics to become less risk exposed in a global financial market perspective, and become more innovative and ethical directed.
\end{abstract}

Keywords: Oil fund policy, risk management, ethics

Some facts on Norwegian oil and gas resources ${ }^{1}$.

The Government Pension Fund - Global is saving for future generations in Norway. One day the oil and gas will run out, but the return on the fund will continue to benefit the Norwegian population. The Fund's market value 2017 is about 73340 billion NOK.

${ }^{1}$ Official data from Norwegian Central Bank Investment management 2017. 
The Fund generated an annual return of 5.6 percent from the establishment of Norwegian Central Bank Investment Management in 1998 to the end of 2015, measured in the fund's currency basket. After management costs and inflation, the return was 3.7 percent. The return in dollars was 5.8 percent. $4 \%$ of the Fund value can be used in the national budget. 179.6 billion NOK were transferred to the national budget in 2015.The fund is integrated into the government budget. A fundamental principle of Norwegian fiscal policy is the so-called budgetary rule. It states that over the course of a business cycle, the government may only spend the expected real return on the fund, estimated at 4 percent per year. This helps to gradually phase oil revenue into the economy. Spending just the return of the fund rather than eating into its capital means that the fund will also benefit future generations and their welfare. The Fund is investing money in 78 different countries, in 9050 companies, and $1.3 \%$ of them are European companies. This means not domestic venture capital and entrepreneurship but only risk capital invested abroad (Shane and Venkataraman 2000).

\section{Norwegian oil capital is risk capital not venture capital targeting entrepreneurship.}

The Government Report No. 24 (2006-2007) to the Parliament (Stortinget), 'On the Management of the Government Pension Fund', presented a very optimistic view on the risks involved but not on venturing actions. Taking as a point of departure that the risk-return profile of the Pension Fund is largely determined by the governmental investment guidelines, the report continues this way: 'The risk assumed in active management has only to a limited degree increased the actual market risk of the Fund...' (Government Report No. 24 (2006-2007): 82). This statement is often repeated also in 2017.

There is, however, no simple way of conceiving risk-regulation regimes. No one has ever seen a risk-regulation regime embracing a totality of effects - and side-effects - along all dimensions. Against this background, Christopher Hood, Henry Rothstein, and Robert Baldwin have stated (2001: 179) that, "principles that have been advanced for regulatory assessment typically comprise some mix of "economic rationalist" cost-effectiveness criteria together with rule-of-law criteria - such as proportionality and transparency - and policy evaluation to identify regulatory impacts and alternatives'

We can recognise the meaning of this quotation in the Norwegian Petroleum industry and the establishment of the Pension Fund - Global. With regard to the optimistic view on risk occurrence and the Pension Fund Global cited from the Government, as we have seen, there are good reasons to doubt this low assessment of the market risk of the Pension Fund. We 
should ignore neither the regular cycle of global economic crises nor the connection between global warming and $\mathrm{CO} 2$-emissions from petroleum activities, which is kept outside risk assessments.

The notion of 'actual market risks' with regard to the future of the Pension Fund is far too narrow for a sufficient evaluation in the service of the common good. In a political and ethical perspective, the Norwegian Pension Fund - Global should not, by definition, represent risk capital in the terms of neo-classical liberal economic thinking but venture capital stimulating innovation and entrepreneurship (Busenitz, L., et al. 2003). Contextually, substantial regulations by law and ethics deviate from regulations only by the market.

\section{The dilemma; foreign investments versus domestic investments}

"What does Norway get out of its Oil Fund (Government Pension Fund - Global (GPF-G)), if not more Strategic Infrastructure Investment, is Michael Hudson asking" (Hudson 2011). He keeps on asking: "What do Norwegians get out of these financial savings, besides a modest interest and dividend yield? Innovation and entrepreneurship? The export surplus is said to be too large to spend more than a small fraction (a Procrustean 4 percent) at home without causing inflation"? So other countries get not only Norway's petroleum, but also most of the royalties and earnings from its production. Meanwhile, Norway spends little on itself, more accurately on infrastructure and entrepreneurship. Even now its financial managers are beginning to worry about how risky the stock markets are becoming and feel the need to diversify investments into real estate. The Norwegian government still avoid investing the Pension Fund's wealth to build up the domestic infrastructure. This might happened in the near future, has the Norwegian Government promised. Michael Hudsons critical analysis goes further like this.

What seems ironic is that while Norway is invested its oil capital savings mainly in European and U.S. financial markets, money managers in these countries are reinvested these money overseas to the BRICS economies (Brazil, Russia, India, China and South Africa). This system contains investment risks not venture. These geographical widespread investments reduce risk to Norway and return earnings directly to make the economy more competitive and benefits the survival of the welfare state. The Pension Fund goes beyond the purely financial scope of decision, simply what foreign stocks and bonds to buy. The basic financial scope of question is which securities will achieve the highest rate of return or rise most quickly in price. This is a short-term decision. Little of this financial acrobatic policy adds value to the real capital of the Norwegian economy nor as venturing capital or welfare. 
Given this situation, how should Norway best policy look like? (Veggeland 2011). As a point of departure, the Norwegian government has a broader option than merely to steer savings into foreign financial markets. The policy should improve the economy by creating tangible means of production to raise productivity by working in tandem with leading national industries, generate innovation and entrepreneurship by give investment in research priorities, and favor building infrastructure, social as well as physical infrastructure. And rather than being inflationary, public investment enabled economies to minimize their cost of living and doing business.

There are two approaches to how the Norwegian government may manage their Pension Fund - Global. For simplicity, these can be called the passive and active approaches. The present approach is passive. Norway consigns its petroleum "earnings to money managers to buy stock or bond ownership abroad without linking these purchases to its own future development - except by receiving a modest foreign exchange return" (Hudson 2011:3). The more active approach considers the government's duty as being to develop the domestic economy to the benefit of its citizens. This is best done by initiating infrastructure building, including education and public health care, research and development, support entrepreneurship and investment in transportation, power generation and distribution, communications and information technology.

Public infrastructure represents the largest capital expenditure in almost every country, yet little trace of its economic role appears in today's Norwegian income and product accounts. Free market ideology wrongly treats public spending as deadweight, and counts infrastructure spending as part of the deficit, not as productive capital investment. Nobel Prize winner 1989, Trygve Haavelmo from Norway, describes the aim of public investment as being different from that of individuals or business. The ultimate aim was not to seek profits, but to create the best economic and social system possible with the resources at hand.

As the Norwegian Prime Minister (PM) since 2005, Jens Stoltenberg, an economist and former Minister of Finance, actually he was the main architect behind the Norwegian Pension Fund - Global (of US \$ 584 bill) and "the budget rule" of not spending more than "an estimated return" of $4 \%$ pro annum. His main argument is that the fund's passive strategy of today is spreading the risk into a multitude of minority positions, and that therefore Hudson's advice of an active strategy and to concentrate investments in national strategic infrastructure and technology will increase the risk rather than reduce the risk. Probably Hudson will respond by arguing that apparently the PM has not understood the industrial motivation of real economic investment (real wealth creation) for Hudson's suggestion as opposed to the financial motivation (monetary profit) that he himself 
pursues. Monetary profit motivates the Pension Fund's investment in stock and bonds global, while domestic wealth creation is passed over by the PM.

The Norwegian government downgrades the monetary profit motive. Instead the Government argues that the potential threat of increased domestic investments will make the Norwegian currency harder against foreign currencies combined with a growing interest rate. The result of this will be loss of economic competiveness internationally because of the currency impact.

\section{The dilemma; negative ethical exclusion versus innovative positive selection}

Thus far, the Ethical Council, which monitors the Government Pension Fund - Global (GPF-G) investments has sought to meet its ethical objectives through so-called negative selection, i.e. exclusion of companies for unethical behavior picked out from the large universe of investments. As we know these may be companies that violate human rights, use child labor, fail to observe ordinary standards for employee rights, manufacture nuclear weapons or cluster munitions, are responsible for severe environmental damage, etc.

Ethical management of the GPF-G could be exercised in two different manners; by negative exclusion or positive selection. For some years now, in the public debate, it has been proposed that the ethical management should be reoriented from negative screening to innovative positive selection. Instead of excluding companies that violate the decided ethical standards, one should invest only in companies and branches that appear to be, in some sense, an active force for the good on ethical issues. Thus, Th. Johnsen and O. Gjølberg (2009:2) write:

".. positive selection involves a significant narrowing of the investment universe. It is, generally speaking, much more difficult to declare a company to be completely without blame than completely beyond the realm of the ethically acceptable. The potential fallout from error under a pure positive selection strategy may also be much higher than under a negative selection strategy".

Of course, they are right, and consequently Norway has chosen the easiest way; negative exclusion (Veggeland 2009). Following up their conclusion, Johnsen and Gjølberg suggest a number of more pragmatic approaches that could be realized by decisions in the Ethical Council. One such approach they suggest for Norway is the "popular principle" of selecting positively the best-in-class strategy. This principle, they postulate, entails selecting those companies that are perceived, based on various ethical criteria, to be best in their class of type-production. The class may be defined as an industry (energy, consumer goods, finance, etc.), but it is also possible 
to define classes as type-production dominant for a particular region. This indicates that a firm may be the best in an ethical poor class, and should be rewarded with investments, and another relatively good ethical firm may be far from the top of the elite ethical and sustainable class of type-production, and investment should be withdrawn. This ranking principle as a pragmatic approach to the political will of realize positive selection more strongly has never been accepted in Norway as a policy for the GPF-G and ethical investments. The reason for that seems to be the problem of ranking. In the jungle of firms and branches it is almost technically impossible to figure out indicators, criteria and measures to make the ranking relevant.

What actually is a more relevant policy approach for Norway in this context is that criteria have been introduced in recent years, which are directed investments for stimulating the growth of upcoming entrepreneurship, of pioneering firms and branches, which concentrate on sustainable production for the future. Thus, in line with international trends, the criteria, the Fund favors in particular investment in companies within environmental technology, solar energy, and renewable energy in general, etc. The literature often refers to these criteria as 'pioneer screening'. Such selection strategies are premised on the idea that companies that make a positive contribution to the climate - or to the fight against AIDS and malaria - generate positive ethical externalities. Of course, this pioneering screening policy is not an unproblematic one. Obviously, new ethical conflicts or dilemmas may arise. When eventually the pioneering typeproduction becomes a commercial success in the global market normally and most likely negative externalities of ethical relevance arise. A randomly chosen example is given by Johnsen and Gjoelberg: Pioneering screening can trigger investments in a pharmaceutical company that devotes a large share of R\&D resources on developing a low price anti-malaria drug that is affordable for poor people in Africa. NPF-G supports such investments. However, this company may at the same time be conducting large-scale animal testing or producing unhealthy drugs. In the Norwegian debate on the GPF-G it has also been proposed that the management of the Fund should focus on investments for helping forward entrepreneurship, economic growth and poverty alleviation in developing countries. This perspective contains interesting views and raise entirely new ethical issues and challenges, in particular as far as positive selection is concerned. It is regrettable, but corruption and poverty do tend to co-exist, making it difficult to combine positive selection based on a company's ethical track-record and investments in developing countries. As observed and for the corruption problem, the NPF-G's positive selection is therefore often biased in favor of well-established, large companies in the rich countries. 


\section{Compliance with Ethical Standards}

- Disclosure of potential conflicts of interest; None potential conflicts of interest.

- $\quad$ Research involving human participants and/or animals; Ethical approval: This article does not contain any studies with human participants or animals performed by any of the authors.

- Informed consent; Yes.

- $\quad$ An academic study, not funded by anyone.

\section{References:}

1. Busenitz, L., et al., 2003. Entrepreneurship Research in Emergence: Past Trends and

2. FutureDirections. Journal of Management, 29(3): 285-309.

3. Hood, Christopher, Rothstein, Henry and Baldwin, Robert (2004), The Government of Risk. Understanding Risk Regulation Regimes, Oxford: Oxford University Press.

4. Hudson, Michael (2011), What Does Norway Get Out Of Its Oil Fund, if Not More Strategic Infrastructure Investment? Working Paper No. 657, Levy Economics Institute of Bard College.

5. Johnsen, Thore and Gjølberg, Ole (2009), Management of Norwegian Oil Funnd: The Challenges and Costs of Being Ethical, Beta 01/2009

6. Shane, S. and Venkataraman, S. 2000. The promise of entrepreneurship as a field of research. Academy of Management Review, 25: 217-226.

7. Veggeland, Noralv (2009), Taming the Regulatory State. Politics and Ethics, Cheltenham, UK - Northampton, MA, USA: Edward Elgar.

8. Veggeland, Noralv (2011), Den nye reguleringsstaten. Idébrytninger og styringskonflikter. (The New Regulatory State. Conflicting ideas and governance trends), Oslo: Gyldendal Akademisk.

\section{Official Reports}

9. Report No 24. (2006-2007) to the Storting, On the Management of the Government Pension Fund in 2006, Ministry of Finance, Norway. 